\title{
Deforestation Dynamics in the Nova Bonal Sustainable Development Project, Acre, Brazil
}

\author{
Silvania Arreco Rocha ${ }^{1}$ (D), Eraldo Aparecido Trondoli Matricardi ${ }^{2}$ (D), \\ Eder Pereira Miguel ${ }^{2}$ (D), João Luiz Lani ${ }^{1}$ (D), \\ Charles Henderson Alves de Oliveira ${ }^{3}$ (D), Alcides Gatto ${ }^{1}$ \\ ${ }^{1}$ Universidade Federal de Viçosa (UFV), Viçosa, MG, Brasil \\ ${ }^{2}$ Universidade de Brasília (UnB), Brasília, DF, Brasil \\ ${ }^{3}$ Instituto de Mudanças Climáticas e Regulação de Serviços Ambientais (IMC), Rio Branco, AC, Brasil
}

\begin{abstract}
This study assessed the dynamics of the land use and cover changes, deforestation trends and the current status of the Legal Forest Reserves (LFR) and Permanent Protected areas (PPA) in the Nova Bonal Sustainable Development Project (SDP) between 1997-2014. Deforestation datasets and fieldwork were used in this analysis. Our results indicate that there was no trend in the estimated deforestation rate dataset for the SDP, but there was a decreasing trend in deforestation rates within its $10-\mathrm{km}$ buffer zone, most likely due to the scarcity of native forests in that area. The negative environmental area balance of PPA and LFR were observed within the 10-km buffer zone of the SDP. Finally, we conclude that the alternative land and forest uses enforced within the SDP are more effective for environmental conservation than the commonly adopted land uses, especially pastures adopted by conventional colonization located around it.
\end{abstract}

Keywords: settlement project, geoprocessing, Amazon. 


\section{INTRODUCTION AND OBJECTIVES}

The continued growth of the human population associated with the quest for survival or increased economic returns has led to the conversion of primary forests into other land use types, resulting in a series of changes in the environment. Deforestation in the Brazilian Amazon has become a topic of international interest due to the importance of the biome for maintaining environmental, social and economic benefits of global interest.

Several studies highlight the importance of forests in maintaining environmental balance through the ecosystem services available according to the type of land use (Castro \& Andrade, 2016; Kremen \& Miles, 2012). Other studies refer to the importance of forests in mitigating climate change resulting from deforestation (Soares Filho et al., 2010; Zhang et al., 2015). Several aspects have been investigated focusing on deforestation and forest degradation (Alencar et al., 2015).

There are several causes of accelerated deforestation in the Brazilian Amazon which include the expansion of cattle ranching, cutting and burning agriculture, logging (mostly illegal and predatory) and commercial agriculture (Arraes et al., 2010; Fearnside, 1987, 2001; Rivero et al., 2009). However, the agents and drivers of deforestation may vary in different parts of the Amazon region over time (Fearnside \& Graça, 2006).

According to Fearnside (2005), the largest variations in the deforestation rate are associated with macroeconomic factors, such as the availability of capital and the inflation rate. For Fearnside (2005), this fact indicates that most deforestation is carried out by those who invest in medium and large cattle farms, and to a lesser extent by small farmers who are based on their labor force. Large landowners are more sensitive to economic changes, such as interest rates, government subsidies for agricultural credit, inflation rates, and land prices.

In another study, Fearnside (2006) states that generally large and medium-sized landowners are primarily responsible for deforestation in the Brazilian Amazon. However, Fearnside (2006) warned that smallholders can substantially contribute to deforestation in areas where they are grouped.

In a study conducted in the state of Pará, Calandino et al. (2012) investigated the contribution of rural settlements to deforestation based on an analysis of $15 \%$ of the federal settlements in that state. The author observed that there was greater deforestation in the settlements than in the surrounding area. However, when the protected areas (conservation units and indigenous lands) were disregarded, their results indicated lower average of annual deforestation rates in settlements compared to the external area.

An analysis of settlements created in the Legal Amazon over the decades indicates that more recently established settlement projects showed a lower deforestation rate compared to the older ones. In the 1990 s the projects implemented an account for $32 \%$ of the total area currently occupied by agrarian reform in that region, while agrarian reform areas created between 2000 and 2011 represent $44 \%$ of the total. When analyzing the deforestation percentage in the region, it was observed that $57 \%$ was concentrated in those settlements established between 1990 and 1999 (Incra, 2014).

Additionally, rural settlements show a different socioeconomic logic from large-scale agriculture and other forms of capitalist production and are responsive for the socioeconomic context to which they belong. This socioeconomic context contributes to maintaining integrating links with the society, as Wanderley (2009) considered while assessing family agriculture.

These facts only increase the analysis complexity of the agents that induce deforestation in the Amazon, since it may vary with the particularities of each state or place. For example, deforestation in private properties in the state of Pará is related to factors such as land grabbing and real estate speculation (Loureiro \& Pinto, 2005). On the other hand, settlements located near major highways present a higher deforestation rate (Barni et al., 2012; Rodrigues \& Pinheiro, 2011).

Based on this controversy about the contribution to deforestation by the agrarian reform settlements, this study intended to assess the deforestation dynamics within the Nova Bonal Sustainable Development Project (PDS) and its surroundings. Additionally, we evaluated the effectiveness of compliance with the Brazilian Forest Code in the Legal Reserve Areas and Permanent Preservation Areas (PPA) in this project modality of man-to-field setting in the Brazilian Amazon. 


\section{MATERIALS AND METHODS}

\subsection{Identification and description of the study area}

The study area involved the Nova Bonal Sustainable Development Project (SDP) and the zone of direct influence in its surroundings. This modality of sustainable development project was created by the Ordinance/Incra/P no. 477 of November $4^{\text {th }}, 1999$, which is considered of social and ecological interest and oriented to support extractive populations for the development of subsistence activities based on extractivism, family agriculture, and other human activities of low environmental impact. The Nova Bonal SDP is located in the municipality of Senador Guiomard and the surrounding area comprises part of five municipalities: Senator Guiomard, Rio Branco, Acrelândia, Plácido de Castro and Porto Acre (Figure 1).

An area of 11,674.9 hectares of Nova Bonal SDP and another 91,799.3 hectares in its surroundings (10-km buffer zone), totaling 103,474.2 hectares, were considered in this study. In order to define the area of direct influence (environment) of the Nova Bonal SDP, it was considered that even though it is not a Conservation Unit, it has a strong sustainability bias that makes it possible to adopt the criteria for defining the boundary established by Conama Resolution no. 13, of December of 1990, that disposes norms referring to the activities developed around Conservation Units. This Resolution determines that human activities in an area with a radius of $10 \mathrm{~km}$ around conservation units are subject to specific norms and restrictions.

The Nova Bonal SDP was created by Ordinance no. 21 of July $5^{\text {th }}, 2005$, published in the Official Gazette no. 132 of July $12^{\text {th }}, 2005$, Section 1 , page 90 , when the Bonal Farm was purchased by the National Institute of Colonization and Agrarian Reform (Incra). Prior to the creation of the Nova Bonal SDP, the major economic activity on that farm was latex extraction from rubber trees. Due to the low price of rubber in the national and international markets, peach palms were subsequently planted for palmito/palm heart commercialization, which became the main economic activity on the farm until the end of the 90's.

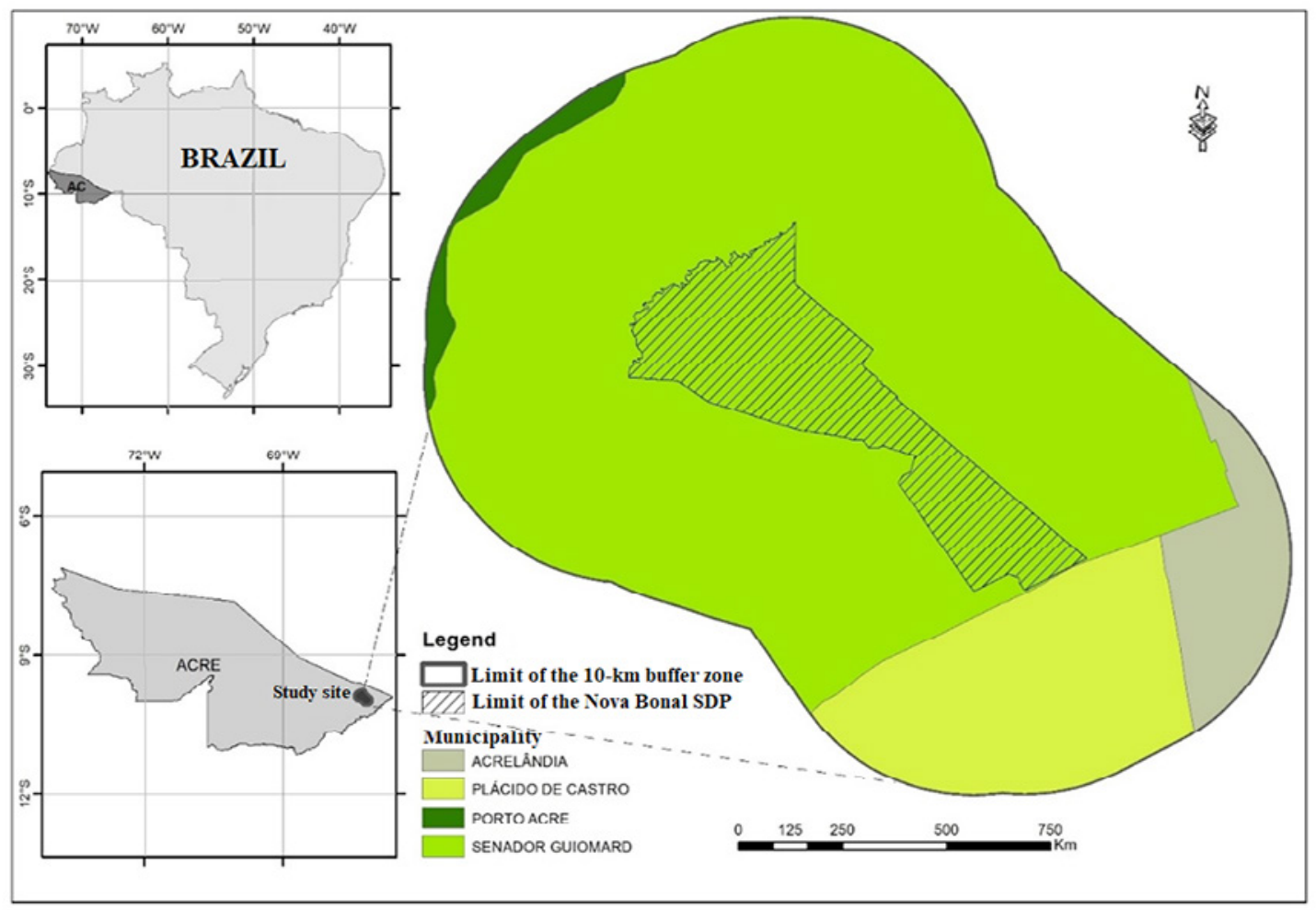

Figure 1. Location of the Nova Bonal SDP and the 10-km buffer zone around it. 
In 1999, former farm employees who had been dismissed in the late 1970s but had remained in the area began to claim the farm for agrarian reform. At the same time, the Incra worked together with the Acre state government and materialized a model of sustainable settlement in the Amazon region. Therefore, the Sustainable Development Project was created with a differentiated settlement modality, with the settlement being preferentially geared to the sustainable use of the forest by the populations with forestry vocation.

According to the field survey, 211 families are currently living in the Nova Bonal SDP, and are mainly engaged in latex extraction and peach palm planting for palmito/palm heart production. The lots of each producer within the farm mostly have approximately 8 hectares destined to agricultural production and livestock, and 47 hectares located in a collective forest reserve.

The study area (the Nova Bonal SDP and its 10-km buffer zone) is part of Pedro Peixoto's Directed Settlement Project (PAD), created in 1977 through the expropriation of land for land reform purposes. The Pedro Peixoto $\mathrm{PAD}$ is the largest settlement project for agricultural colonization in the state of Acre and one of the marks of the official colonization of the Amazon along the BR-364 highway (Acre, 2006).

\subsection{Database}

The spatial analyses were based on the deforestation dataset available for 1997, 2003, 2006, 2009, 2012, and 2014, acquired from the Deforestation Monitoring Program (Prodes) (Inpe, c2015) in vector format. The drainage network and springs datasets acquired from the Ecological-Economic Zoning database of the state of Acre were prepared at a scale of 1:100,000 (Acre, 2006). Further details of the datasets used in this study are presented in Table 1.
American reference geodetic system of 1969 (Datum SAD-69) was applied, which is a planimetric datum widely used in Brazil. The data that were not in this system were duly converted using the appropriate parameters of cartographic projections and datum.

The deforestation maps classified by Prodes showed a good level of accuracy. Piontekowski et al. (2014) evaluated the accuracy of the deforestation classification developed and conducted by the National Institute of Space Research (Inpe) for the deforestation monitoring program in the Amazon region (Prodes), and compared to reference images (high spatial resolution) acquired by the Spot satellite. Piontekowski et al. (2014) estimated $93.3 \%$ accuracy of the mapping conducted by Prodes-Inpe, which indicates high reliability of the classification and of the estimated deforestation numbers used in this study.

\subsection{Data processing}

The computational application used to manipulate and generate these study results was the 10.2 version of the ArcMap software program. Vector and matrix data were used according to convenience for data processing. When conversion of vector data to matrix data was necessary, a resolution of 30 meters was adopted, which corresponds to the original spatial resolution of the Prodes/Inpe deforestation data.

\subsection{Assessment of the deforestation dynamics and the situation of legal reserves}

From 1997 to 2014, we sought to identify deforestation dynamics in the Nova Bonal SDP and its surroundings (10-km buffer zone) using deforestation data provided by the Prodes project (Inpe, c2015). Based on these data, the deforestation dynamics in the Nova Bonal SDP and its surroundings were compared and the deforestation

Table 1. Database used in this study.

\begin{tabular}{lccccc}
\multicolumn{1}{c}{ Data } & Description & Scale/Resolution & Format & Data & Source \\
Deforestation map & $\begin{array}{c}\text { Deforested/Non- } \\
\text { deforested }\end{array}$ & $1: 100,000$ & Vectorial (shapefile) & $\begin{array}{l}20062009 \\
20122014\end{array}$ & Inpe (Prodes) \\
Hydrography map & & $1: 100,000$ & Vectorial (shapefile) & 2006 & ZEE/AC \\
Map of springs & & $1: 100,000$ & & 2006 & \\
\hline
\end{tabular}

For all the georeferenced data, the UTM coordinate system, zone 19S and the South. 
data were also used to assess deforestation within the Legal Reserve Areas.

The evaluation of the Legal Reserve Area was based on deforestation data of 2014 and Law no. 12.651 of 2012, which establishes that all rural property located in the Legal Amazon should maintain a minimum percentage of $80 \%$ of its area covered with native vegetation when located in a forest area, without prejudice to applying the rules for Permanent Preservation Areas.

\subsection{Evaluation of Permanent Preservation Areas}

The delimitation of the Permanent Preservation Areas (PPA) was based on the limits established by the Law no. 12.651 of 2012 and on the spatial data of the drainage network (rivers and springs). The polygons around the rivers and the springs were generated from these data, which resulted in the PPA. No slope greater than $45^{\circ}$ were observed in the study area, which is predominantly characterized by smooth undulating relief.

According to Law no. 12.651, the rivers with a width of less than 10 meters, as in the case of the most rivers (igarapés) in the Nova Bonal SDP and its surroundings, a buffer zone of 30 meters was adopted on both sides to define the PPA. For springs (permanent and intermittent), a minimum radius of 50 meters was applied, which is considered a sufficient spatial dimension to preserve them. Small artificial lakes (reservoirs) were observed during our field study, but they were not detected by the ZEE hydrographic mapping of the state of Acre (Acre, 2006).

\section{RESULTS AND DISCUSSION}

\subsection{Deforestation dynamics}

The analysis of Prodes dataset (Table 2) showed that approximately 143.5 hectares (annual average of 10.3 hectares) were deforested between 1997 and 2014 in the Nova Bonal SDP and 24,927.4 hectares (annual average of 2,572.5 hectares of deforestation) in the $10-\mathrm{km}$ buffer zone of its surroundings. There was no substantial change in forest reduction within the Nova Bonal SDP, while major changes in its surroundings occurred between 1997 and 2006, with a substantial decrease of native forests.

Table 2. Deforestation in the study area (Nova Bonal SDP and around a 10-km buffer zone) between 1997 and 2014.

\begin{tabular}{|c|c|c|c|c|c|c|c|c|}
\hline \multirow{3}{*}{ Year } & \multicolumn{4}{|c|}{ Nova Bonal SDP } & \multicolumn{4}{|c|}{$10-\mathrm{km}$ buffer zone } \\
\hline & \multicolumn{2}{|c|}{ Forest } & \multicolumn{2}{|c|}{ Deforestation } & \multicolumn{2}{|c|}{ Forest } & \multicolumn{2}{|c|}{ Deforestation } \\
\hline & Hectare & $\%$ & Hectare & $\%$ & Hectare & $\%$ & Hectare & $\%$ \\
\hline 1997 & $10,029.60$ & 85.9 & $1,645.30$ & 14.10 & $49,619.80$ & 54.1 & $42,179.53$ & 45.9 \\
\hline 2000 & $10,007.20$ & 85.7 & $1,667.70$ & 14.30 & $42,599.80$ & 46.4 & $49,199.59$ & 53.6 \\
\hline 2001 & $10,002.00$ & 85.7 & $1,672.80$ & 14.30 & $39,218.20$ & 42.7 & $52,581.17$ & 57.3 \\
\hline 2002 & $9,988.30$ & 85.6 & $1,686.60$ & 14.40 & $34,188.30$ & 37.2 & $57,611.07$ & 62.8 \\
\hline 2003 & $9,982.00$ & 85.5 & $1,692.90$ & 14.50 & $32,102.80$ & 35 & $59,696.54$ & 65 \\
\hline 2004 & $9,981.10$ & 85.5 & $1,693.80$ & 14.50 & $30,099.20$ & 32.8 & $61,700.19$ & 67.2 \\
\hline 2005 & $9,975.40$ & 85.4 & $1,699.50$ & 14.60 & $26,952.80$ & 29.4 & $64,846.51$ & 70.6 \\
\hline 2006 & $9,968.70$ & 85.4 & $1,706.20$ & 14.60 & $26,467.80$ & 28.8 & $65,331.56$ & 71.2 \\
\hline 2007 & $9,958.10$ & 85.3 & $1,716.80$ & 14.70 & $25,977.60$ & 28.3 & $65,821.79$ & 71.7 \\
\hline 2008 & $9,958.10$ & 85.3 & $1,716.80$ & 14.70 & $25,801.10$ & 28.1 & $65,998.25$ & 71.9 \\
\hline 2009 & $9,940.20$ & 85.1 & $1,734.70$ & 14.90 & $25,554.60$ & 27.8 & $66,244.75$ & 72.2 \\
\hline 2010 & $9,940.20$ & 85.1 & $1,734.70$ & 14.90 & $25,421.90$ & 27.7 & $66,377.46$ & 72.3 \\
\hline 2011 & $9,928.00$ & 85 & $1,746.90$ & 15.00 & $25,196.50$ & 27.4 & $66,602.81$ & 72.6 \\
\hline 2012 & $9,916,10$ & 84.9 & $1,758.80$ & 15.10 & $25,139.20$ & 27.4 & $66,660.19$ & 72.6 \\
\hline 2013 & $9,896.90$ & 84.8 & $1,778.00$ & 15.20 & $24,895.90$ & 27.1 & $66,903.50$ & 72.9 \\
\hline 2014 & $9,886.10$ & 84.7 & $1,788.80$ & 15.30 & $24,692.40$ & 26.9 & $67,106.92$ & 73.1 \\
\hline Total area & & & 9 ha & & & & $.3 \mathrm{ha}$ & \\
\hline
\end{tabular}


The data series of annual deforestation rates (Table 2) analyzed for the Nova Bonal SDP showed a linear behavior and the Cox \& Stuart (1955) test indicates that there is no trend $(0.6875>0.05)$ in the data (Figure 2).

The deforestation data series for the Nova Bonal SDP surrounding region have a linear trend behavior (Figure 3), according to the Cox \& Stuart (1955) test $(0.01565<0.05)$.

The results of the data series analysis indicate low and stable deforestation rates within the Nova Bonal SDP, estimated at approximately $1 \%$ increase between 1997 and 2014. This deforestation rate is expected to meet the demand for implementing the allowed subsistence cropping activities in that project area, which indicates a good level of forest conservation.
The results of the deforestation data in the $10-\mathrm{km}$ buffer zone of the Nova Bonal SDP indicate that there is a tendency to reduce deforestation rates in the study period. Based on our field observations, a reduction in the deforestation rates were expected because most of the remaining native forests had been clear-cut as a result of the intense process of pasture expansion especially observed between 1997 and 2005. This land use change process led to a substantial reduction in forest cover (from $54.1 \%$ to $28.8 \%$ ). Annual deforestation rates as of 2006 were lower, probably due to deforestation of native forest areas (Figure 4). The change in the behavior of deforestation rates around the Nova Bonal SDP over the study period required a linear model (Figure 3 ) to better explain the variation of the deforestation data in the time series.

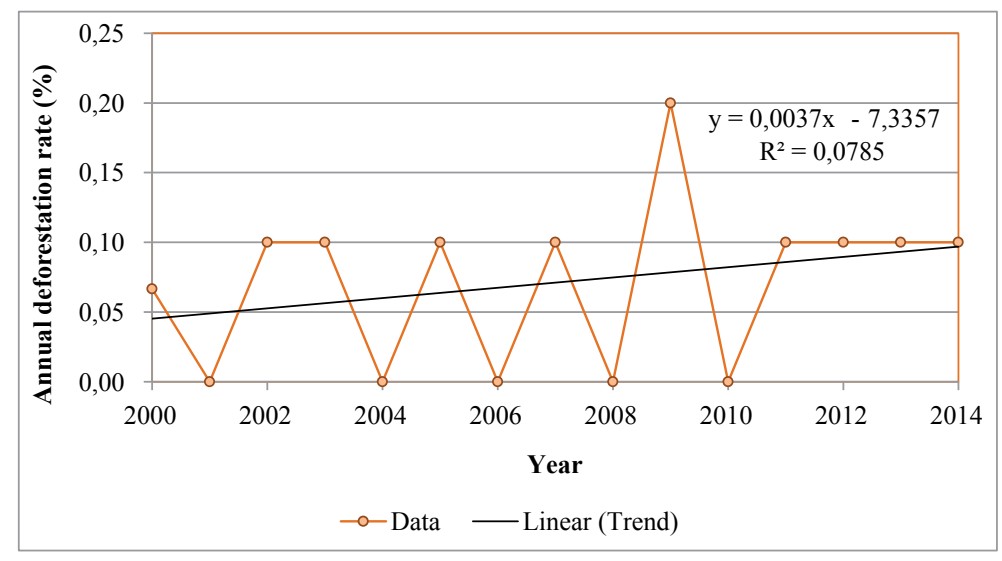

Figure 2. Linear regression model for the dataset of the annual deforestation rates of the Nova Bonal SDP between 1997 and 2014.

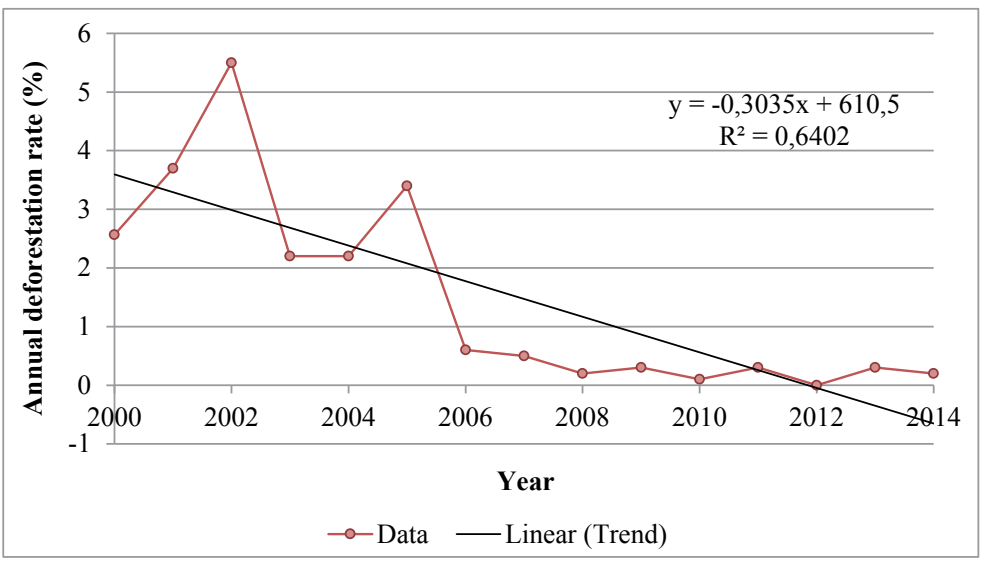

Figure 3. Linear regression model for the deforestation dataset of the Nova Bonal SDP 10-km buffer zone between 1997 and 2014. 


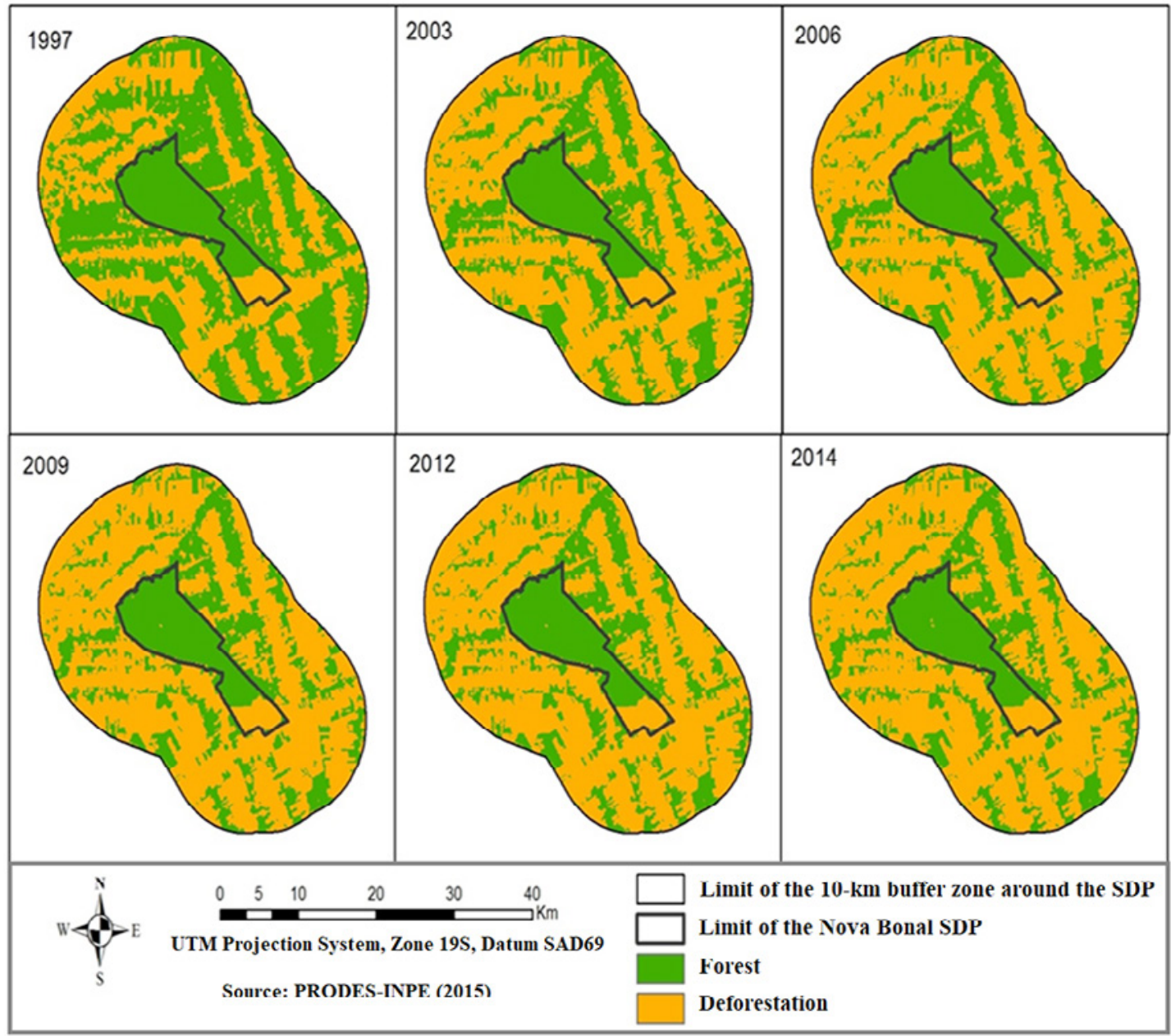

Figure 4. Deforestation dynamic within the study area (Nova Bonal SDP and around a 10-km buffer zone of the Nova Bonal SDP) between 1997 and 2014.

Small forest cover changes in the Nova Bonal SDP were observed from the beginning of its occupation (end of 2005 and beginning of 2006) by the current residents until 2014. Forest cover was reduced from $85.4 \%$ to $84.7 \%$, which indicates that little of the native vegetation was clear-cut after the implementation of this type of settlement project. Accumulated deforestation around the Nova Bonal SDP was also low in the same period, (Figure 5), with native vegetation percentage decreasing from $29.4 \%$ to $26.9 \%$.

Although the annual deforestation rates in the Nova Bonal SDP surrounding area have stabilized $(<1 \%)$ after 2005 (Figure 6), the total deforested area was much higher than that observed within the Nova Bonal SDP. In the case of the Nova Bonal SDP, it was observed very low annual deforestation rates during the study period and the total remaining forest area was well below the $80 \%$ of legal reserve defined by the Forest Code in force.

Finally, we estimated that $84.7 \%$ and $26.9 \%$ of the forest cover remained in and around the Nova Bonal SDP, respectively, until 2014. These results indicate that deforestation was substantially lower in the Nova Bonal SDP than in conventional farms, especially those engaged in agricultural activities located in its surroundings.

A deforestation analysis of the surroundings (10-km buffer zone around the Nova Bonal SDP), a zone located within the Pedro Peixoto Directed Settlement Project (PAD), indicates that a common behavior has been occurring which has also been previously observed in the oldest agrarian reform settlements in the Amazon region, where native forests are progressively converted into anthropogenic land use. Incra's lack of support led 


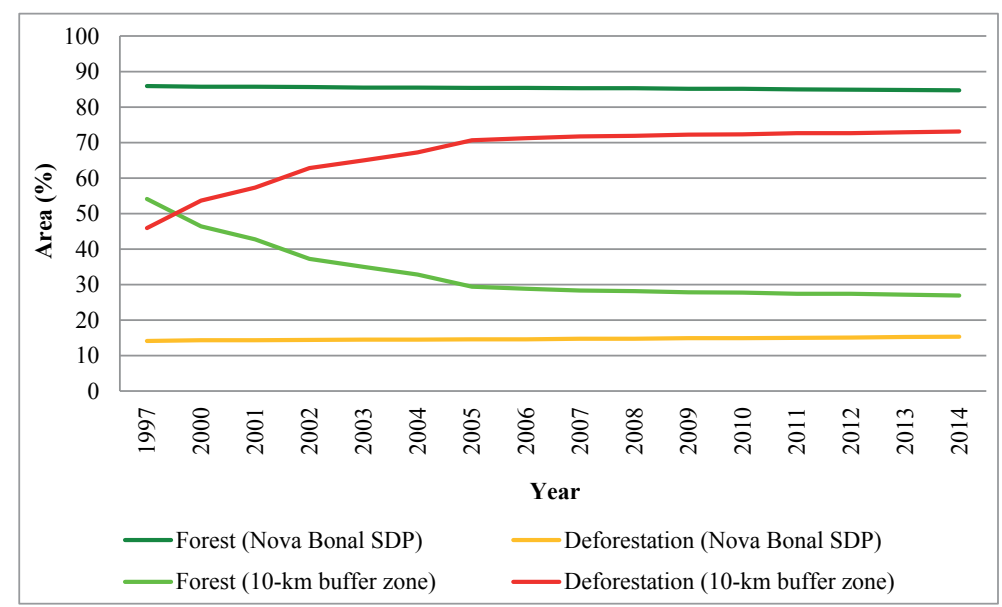

Figure 5. Land use and land cover changes in the study area (Nova Bonal SDP and around a 10-km buffer zone) between 1997 and 2014.

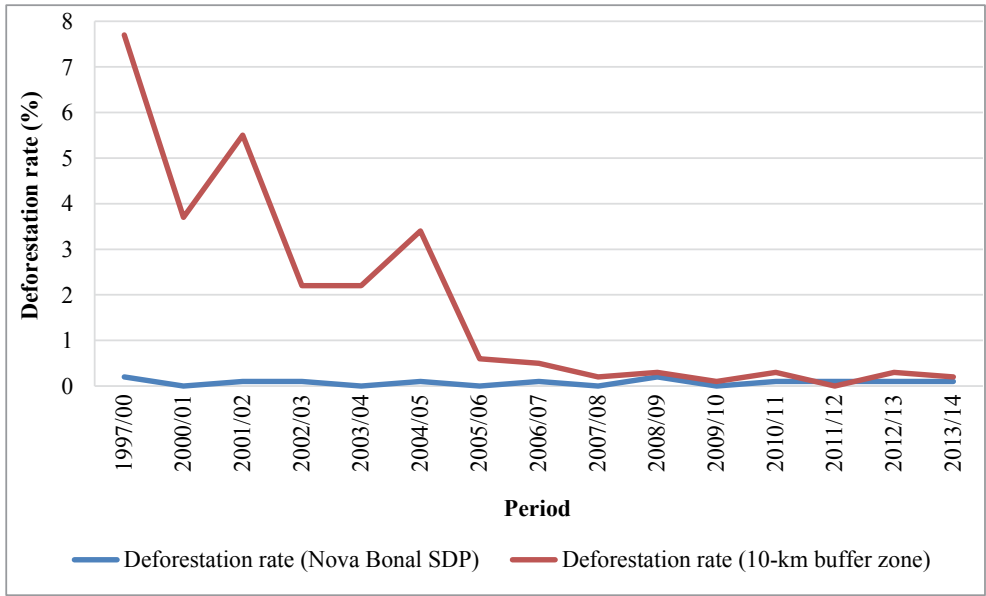

Figure 6. Deforestation rates in the study area (Nova Bonal SDP and around a 10-km buffer zone) between 1997 and 2014.

settlers to frequently exploit the most abundant forest resource to net higher profits (tropical timber) (Calandino et al., 2012). Incra only integrated environmental liabilities into its actions after the end of the 1990s (Le Tourneau \& Bursztyn, 2010).

The Pedro Peixoto Direct Settlement Project was officially established in 1977 and 20 years later (in 1997) there was only $54 \%$ of its native vegetation, although the percentage of native vegetation when the Pedro Peixoto settlement was established is unknown. In that case, most of the areas previously covered with native vegetation are now covered with pastures, which is the main economic activity in the Amazon region (Arraes et al., 2010; Eiró \& Tricaud, 2010; Rivero et al., 2009).
The expansion of the agricultural and selective logging frontier in the state of Acre began in the 1970s (Lemos \& Silva, 2011). According to Rivero et al. (2009), among the factors that motivate the expansion of livestock production in the Amazon are low capital levels, low soil preparation requirements, and few restrictions associated to relief characteristics.

However, what is observed is that most of the properties do not belong to the first owners, which indicates that most of the families that first owned the land took advantage of the official (mostly free) land distribution by the federal government. There are currently numerous properties of up to 100 hectares whose predominant land use is pastures. Based on this, we infer that the most part 
of deforestation which occurred since 1997 was mainly enforced by landowners who purchased those lands after the first occupation cycle in that region.

Further details observed in Figure 3 show that there has been a stabilization of deforestation in the surrounding area of the SDP since 2005, which may be due to the fact that the vegetation is well below the minimum percentage required by the environmental law. However, according to deforestation data in the Amazon between 2000 and 2010 (Imazon, 2013; Inpe, c2015), there was a significant decrease in deforestation rates in the state of Acre since 2005. According to Fearnside (2017), the reduction in deforestation rates in the Amazon was influenced by the variation in economic cycles, with deforestation peaks until 2004, and a decrease in subsequent years.

Figure 4 shows that there was greater loss of native vegetation around the Nova Bonal SDP. Figure 4 also shows two deforestation peaks around the Nova Bonal SDP; one between 2001 and 2002, and another between 2005 and 2006, probably associated with macroeconomic factors (Fearnside, 2017).

In the Nova Bonal SDP settlement, the percentage of forest cover was above those estimated for most agrarian reform settlements (Batistella \& Moran, 2005; Capoane \& Santos, 2012; Lemos \& Silva, 2011; Soares \& Espindola, 2008), which indicates an atypical situation among those settlements, whether located in the Amazon or not. However, the Nova Bonal SDP was previously considered an agroforestry property with more than $80 \%$ of its original forest coverage and, subsequently, created to be a model of agrarian reform.

Based on this, we observed that the alternative land use in the Nova Bonal SDP oriented to conserve the remnants of tropical forests worked properly until 2014. Based on field observations and information and on the Incra Regional Office in the state of Acre (Incra-SR/14), we can affirm that the determining factors for the success of forest maintenance in the Nova Bonal SDP were the creation of a new type of settlement project, as well as a better and stronger rural technical assistance enforced by Incra aiming to fulfill previously defined objectives of that settlement project.

As affirmed by Pereira (2007), it was necessary to adopt an agroecological model of rural settlement that allows the integration of social and ecological dimensions for solving land conflicts that arose in the Vale do Rio São João in the state of Rio de Janeiro for creating the Poço das Antas Biological Reserve. In our case study, the SDP, this modality created by Incra, is considered an alternative of sustainable land use in areas located outside of the Conservation Units oriented to forest extraction activities and subsistence agriculture commonly adopted by traditional populations.

\subsection{Legal Reserve and Permanent Preservation Area (PPA)}

By 2014, the Legal Reserve Areas encompassed approximately $85 \%$ and $27 \%$ in the Nova Bonal SDP and its surroundings, respectively (Table 3 ). Based on the current Forest Code, which defines $80 \%$ of Legal Reserve for forests in private properties located in the Brazilian Amazon, the Nova Bonal SDP did not show an environmental deficit of Legal Reserve by 2014. Most of the original vegetation in the surroundings of Nova Bonal SPD was converted into another land usage type, and therefore we assumed that most of the rural properties located in this area of the surroundings show deficit of Legal Reserve Areas.

Based on this study field data, no presence or very low percentages $(<80 \%)$ of native vegetation was observed in most of the private properties visited around a $10-\mathrm{km}$ buffer zone. We also observed that selective logging activities practiced by residents of the project have increased within the Nova Bonal SDP, and mainly by residents of its surroundings.

Permanent Preservation Areas (PPAs) located along the water bodies in the Nova Bonal SDP and in the surroundings include approximately 627.2 ha and $3,745.8$ ha, respectively. Approximately $86.5 \%$ and $34.1 \%$

Table 3. Forest cover in the study area (Nova Bonal SDP and around a 10-km buffer zone) by 2014.

\begin{tabular}{ccccc}
\multirow{2}{*}{ Location } & \multicolumn{4}{c}{ Area by 2014 } \\
\cline { 2 - 5 } & Forest (ha) & Deforestation (ha) & Total (ha) & Forest (\%) \\
Nova Bonal SDP & $9,886.1$ & $1,788.8$ & $11,674.9$ & 84.7 \\
\hline 10-km buffer zone & $24,692.4$ & $67,106.9$ & $91,799.3$ & 26.9 \\
\hline
\end{tabular}


Table 4. Forest cover in the Permanent Protected Areas of the Nova Bonal SDP and around the 10-km buffer zone by 2014 .

\begin{tabular}{|c|c|c|c|c|c|}
\hline \multirow{2}{*}{ APPs } & \multicolumn{2}{|c|}{ Nova Bonal SDP } & \multicolumn{2}{|c|}{ 10-km buffer zone } & \multirow{2}{*}{$\begin{array}{c}\text { Total } \\
\text { ha }\end{array}$} \\
\hline & ha & $\%$ & ha & $\%$ & \\
\hline Forest & 542.3 & 86.5 & $1,278.1$ & 34.1 & $1,820.5$ \\
\hline Deforestation & 84.9 & 13.5 & $2,467.7$ & 65.9 & $2,552.6$ \\
\hline Total & 627.2 & & $3,745.8$ & & $4,373.1$ \\
\hline
\end{tabular}

are properly preserved, respectively in the Nova Bonal SDP and in its surroundings (Table 4).

Based on this study's results, the Nova Bonal SDP showed a $13.5 \%$ environmental deficit of the PPAs. This result is much better than those observed in its surroundings and in other conventional rural settlements located in the Amazon and other regions, which indicates a good conservation level of natural resources that depends on the amount of native vegetation.

However, both PPA and Legal Reserve preservation depends on legal and technical measures that may allow the residents to use forest sustainably in order to avoid people from outside the Nova Bonal SDP from using the natural resources of that collective reserve. Environmental service payments for the Nova Bonal SDP would be an economical alternative to protect the native vegetation in that area. Also, those environmental services would be a good alternative to improve the socioeconomic conditions of the Nova Bonal SDP and contribute to preserving native vegetation and resources that depend on the forest conservation.

\section{CONCLUSIONS}

Deforestation data observed within the Nova Bonal SDP indicate that there was no trend in annual deforestation rates, with stable behavior and at low levels throughout the analyzed period (1997 and 2014). The deforestation data for the area surrounding the Nova Bonal SDP indicates a decreasing trend of annual deforestation rates for the same period, with the highest deforestation rates observed between 1995 and 2005, which indicates that it was a boom period of deforestation. As of 2005, the deforestation rates observed for the surroundings of the Nova Bonal SDP were lower $(<0.5 \%)$ because of the forest scarcity that was legally suitable to deforestation in the study region and other external factors, such as the change in economic cycles in Brazil.
Finally, it was observed that more than $80 \%$ of the Nova Bonal SDP forest cover was conserved until 2014, which is in compliance with environmental legislation. However, only $27 \%$ of native forests in the surroundings of the Nova Bonal SDP were conserved until that year. This indicates that the traditional land colonization model in the Amazon was the major factor responsible for deforestation in the region and study period. The alternative sustainable development project model, as previously defined for creating the Nova Bonal SDP, showed great efficiency to improve environmental sustainability in the study region.

\section{ACKNOWLEDGEMENTS}

We acknowledge that the work was supported by the Forestry Graduate Program at University of Brasília, the Coordenação de Aperfeiçoamento de Pessoal de Nível Superior (Capes), and the Conselho Nacional de Desenvolvimento Científico e Tecnológico (CNPq). We also thank the anonymous reviewers of the Brazilian Journal of Forestry and Environment for providing further editorial improvements and helping to better the scientific quality of this article.

\section{SUBMISSION STATUS}

Received: 9 Jan., 2017

Accepted: 13 Dec., 2018

\section{CORRESPONDENCE TO}

\section{Eraldo Aparecido Trondoli Matricardi}

Universidade de Brasília (UnB), Faculdade

de Tecnologia, Departamento de Engenharia

Florestal, Av. L3, s/n, Asa Norte, CEP 70910-900,

Brasília, DF, Brasil

e-mail: ematricardi@gmail.com 


\section{REFERENCES}

Acre. Governo do Estado. Programa estadual de zoneamento ecológico-econômico do Acre. Rio Branco: Secretaria do Estado do Meio Ambiente; 2006.

Alencar AA, Brando PM, Asner GP, Putz FE. Landscape fragmentation, severe drought, and the new Amazon forest fire regime. Ecological Society of America 2015; 25(6): 1493-1505. 10.1890/14-1528.1

Arraes CL, Rocha AM, Moraes RA, Pissara TCT, Rodrigues FM, Zanata M. Estimativa da taxa de desmatamento dos municípios de Bannach, Pará - Amazônia Legal, utilizando imagens Landsat5/TM. Revista de Ciências Agrárias 2010; 33(2): 231-244. 10.19084/rca.15900

Barni PE, Fearnside PM, Graça PMLA. Desmatamento no sul do estado de Roraima: padrões de distribuição em função de Projetos de Assentamento do Incra e da distância das principais rodovias (BR-174 e BR-210). Acta Amazonica 2012; 42(2): 195-205. 10.1590/S0044-59672012000200003

Batistella M, Moran EF. Dimensões humanas do uso e cobertura das terras na Amazônia: uma contribuição do LBA. Acta Amazonica 2005; 35(2): 239-247. 10.1590/ S0044-59672005000200014

Brasil. Lei n. 12.651, de 25 de maio de 2012. Diário Oficial da República Federativa do Brasil, Brasília, DF (2012 May 25); Sec. 1: 1.

Calandino DWM, Wehrmann M, Koblitz R. Contribuição dos assentamentos rurais no desmatamento da Amazônia: um olhar sobre o estado do Pará. Desenvolvimento e Meio Ambiente 2012; 26: 161-170. 10.5380/dma.v26i0.26017

Capoane V, Santos DR. Análise qualitativa do uso e ocupação da terra no assentamento Alvorada, Júlio de Castilhos - Rio Grande do Sul. Revista Nera 2012 [cited 2019 May 20]; 15(20): 193-205. Available from: https:// bit.ly/2YFYHJj

Castro AS, Andrade DC. O custo econômico do desmatamento da Floresta Amazônica brasileira (19882014). Perspectiva Econômica 2016; 12(1): 1-15. 10.4013/ pe.2016.121.01

Conselho Nacional do Meio Ambiente - Conama. Resolução n. 13, de 6 de dezembro de 1990. Diário Oficial da República Federativa do Brasil, Brasília, DF (1990 Dec. 28); Sec. 1: 25541.

Cox DR, Stuart A. Some quick tests for trend in location and dispersion. Biometrika 1955; 42(1): 80-95. $10.2307 / 2333424$

Eiró F, Tricaud S. Gestão ambiental de assentamentos na Amazônia: estudo de caso do Projeto de Assentamento Juruena. In: Anais do V Encontro Nacional da Anppas; 2010; Florianópolis. Florianópolis: Anppas; 2010.

Fearnside PM. Causes of deforestation in the Brazilian Amazon. In: Dickinson RE, editor. The geophysiology of
Amazonia: vegetation and climate interactions. New York: John Wiley \& Sons; 1987. p. 37-53.

Fearnside PM. Soybean cultivation as a threat to the environment in Brasil. Environmental Conservation 2001; 28(1): 23-38. 10.1017/S0376892901000030

Fearnside PM. Desmatamento na Amazônia brasileira: história, índices e consequências. Megadiversidade 2005 [cited 2019 May 20]; 1(1): 113-123. Available from: https:// bit.ly/2HL7JOy

Fearnside PM. Desmatamento na Amazônia: dinâmica impactos e controle. Acta Amazonica 2006; 36(3): 395400. 10.1590/S0044-59672006000300018

Fearnside PM. Deforestation of the Brazilian Amazon. Oxford Research Encyclopedia of Environmental Science 2017. 10.1093/acrefore/9780199389414.013.102

Fearnside PM, Graça PMLA. BR-319: Brazil's ManausPorto Velho highway and the potential impact of linking the arc of deforestation to central Amazonia. Environmental Management 2006; 38(5): 705-716. 10.1007/s00267-005-0295-y

Instituto de Pesquisas Espaciais - Inpe. Dados do projeto Prodes e do Projeto TerraClass. c2015 [cited 2015 Jan. 10]. Available from: https://bit.ly/2a1U737

Instituto do Homem e Meio Ambiente da Amazônia Imazon. Desmatamento e degradação florestal no bioma Amazônia (2000 - 2010). 2013 [cited 2017 Jun. 20]. Available from: https://bit.ly/2KQ4dWj

Instituto Nacional de Colonização e Reforma Agrária - Incra. Boletim de análise sobre o desmatamento em assentamento na Amazônia. 2014 [cited 2014 Dec. 12]. Available from: https://bit.ly/2JOLtpz

Kremen C, Miles A. Ecosystem services in biologically diversified versus conventional farming systems: benefits, externalities, and trade-offs. Ecology and Society 2012; 17(4): 40. 10.5751/ES-05035-170440

Lemos ALF, Silva JA. Desmatamento na Amazônia Legal: evolução, causas, monitoramento e possibilidades de mitigação através do Fundo Amazônia. Floresta e Ambiente 2011; 18(1): 98-108. 10.4322/floram.2011.027

Le Tourneau FM, Bursztyn M. Assentamentos rurais na Amazônia: contradições entre a política agrária e a política ambiental. Ambiente \& Sociedade 2010 [cited 2019 May 20]; 8(1): 111-130. Available from: https:// bit.ly/2VRgGQa

Loureiro VR, Pinto JNA. A questão fundiária na Amazônia. Estudos Avançados 2005; 19(54): 77-98. 10.1590/S010340142005000200005

Pereira MCB. Reforma agrária e meio ambiente: desafios e possibilidades em torno de conflitos envolvendo assentamentos rurais/Incra e reserva biológica/Ibama. Floresta e Ambiente 2007 [cited 2019 May 20]; 14(2): 49-63. Available from: https://bit.ly/2VEbhqH 
Piontekowski VJ, Matricardi EAT, Pedlowski MA, Fernandes LC. Avaliação do desmatamento no estado de Rondônia entre 2001 e 2011. Floresta e Ambiente 2014; 21(3): 297-306. 10.1590/2179-8087.068213

Rivero S, Almeida O, Ávila S, Oliveira W. Pecuária e desmatamento: uma análise das principais causas diretas do desmatamento na Amazônia. Nova Economia 2009; 19(1): 41-66. 10.1590/S0103-63512009000100003

Rodrigues EP, Pinheiro ES. O desflorestamento ao longo da rodovia BR-174 (Manaus/AM - Boa Vista/RR). Sociedade \& Natureza 2011; 23(3): 513-528. 10.1590/ S1982-45132011000300011

Soares Filho B, Moutinho P, Nepstad D, Anderson A, Rodrigues H, Garcia R et al. Role of Brazilian Amazon protected areas in climate change mitigation. Proceedings of The National Academy of Sciences of the United States of America 2010; 107(24): 10821-10826. 10.1073/ pnas.0913048107

Soares JLN, Espindola CR. Geotecnologias no planejamento de assentamentos rurais: premissa para o desenvolvimento rural sustentável. Revista Nera 2008 [cited 2019 May 20]; 12(11): 108-116. Available from: https://bit.ly/2VNeYiy

Wanderley MNB. O mundo rural como um espaço de vida: reflexões sobre a propriedade da terra, agricultura familiar e ruralidade. Porto Alegre: Editora da UFRGS; 2009.

Zhang K, Castanho ADA, Galbraith DR, Moghim S, Levine NM, Bras RL et al. The fate of Amazonian ecosystems over the coming century arising from changes in climate, atmospheric $\mathrm{CO}_{2}$, and land use. Global Change Biology 2015; 21(7): 2569-2587. 10.1111/ gcb. 12903 